bilization, burn treatment, wound repair, and management of multiple medical problems.

To Blackwell's knowledge, it is the first full-scale hospital treatment facility on wheels. "We call it the ultimate house call," he says.

MED-I was awaiting its first field test when Katrina struck last Aug. 29. Just 5 days later, it left Charlotte, NC, for the Gulf Coast.

The volunteer staff of more than 80 doctors, nurses, paramedics and support personnel cleared trees and other debris from a Waveland Kmart parking lot, and got to work for the next 7 weeks.

Initially, patients had cuts from storm debris, and rashes and skin infections from wading through contaminated floodwaters. The staff also treated car-crash victims and provided followup care to patients who had recently undergone surgery. But the seriously ill patients they expected didn't turn up. Finally, they realized that perhaps many diabetics and cardiac patients hadn't survived without their medications.

The rotating staff, drawn from North Carolina hospitals and trauma centres, slept on cots, and initially took cold showers and lived on ready-to-eat meals.

But there was an upside: "We got back to old fashioned medicine touching people, talking to people, spending more time at patients' beds," says Blackwell. "It was life-changing. People begged to come back."

Six months later, a crew of 15 did return to the Gulf Coast to back up New Orleans' gutted hospital system during Mardi Gras. The city had lost nearly twothirds of its hospital beds and had just 2 functioning emergency departments.

MED-I pulled into a parking lot near the Superdome late one evening and, with the help of more than a dozen local healthcare workers, it was ready to receive patients the next morning. At the time, only 4 hospital beds were free in the city. It stayed 2 weeks.

The blogger who had wondered if officials were expecting a Mardi Gras disaster added a final comment. "At least," he wrote, "they are planning." If he only knew. - Janet Brooks, Salt Lake City, Utah

\section{West Nile virus still a threat}

I t's tempting to conclude that the worst is over, that precautionary measures and the vicissitudes of fate and nature have somehow combined to reduce the health threat posed by the West Nile virus (WNV).

But experts say the lower incidence as of Aug. I2, 2006 (Table I) is hardly an indicator that WNV has been contained, or even a sign that the ultimate incidence will be lower because the WNV season peaks from mid-August through September.

In fact, there's a good possibility WNV rates in Manitoba and Saskatchewan will soon soar as a species of mosquito called Culex tarsalas, a vigorous biter that loves to breed in sun-dried prairie ditches, appears more prevalent this year and "its infectivity rate is up," says Mike Drebot, head of Health Canada's Viral Zoonoses Section.

"The dry hot summer actually can be conducive for more generations of mosquitos and hence, a greater possibility that we're going to get infected mosquitos. And, also, the virus replicates within the mosquito at a higher rate when it's hotter."

The vectors and variables that affect $\mathrm{WNV}$ rates are too poorly understood to safely say the threat is dissipating, adds Drebot. One variable is the fact that birds carrying the virus are becoming "more immune as a population," Drebot says.

But speaking on behalf of the Association of Medical Microbiology and Infectious Disease Canada, Neil Rau says it also appears there's genetic transmission of West Nile within mosquito larvae, "a sort of over-wintering mechanism," so the spread of the virus isn't limited by annual reintroduction from migratory birds.

"It's here to stay and one of the concerns about West Nile is that it does seem to infect numerous different species of mosquitos unlike the old St. Louis Encephalitis virus [which afflicted about 2500 people in North America in the mid I970s]. This means that WNV has a much larger environmental niche in terms of mosquito species and a much greater geographic distribution," adds Rau, the medical director of infection, prevention and control for Halton Health Care Services in Ontario. "It also seems very hardy, in that it can tolerate continental climates that are quite north."

The experts concede this year's lower incidence may be partially attributable to mosquito abatement programs, particularly in large urban cen-

Table 1: Number of human cases of West Nile virus infection in Canada, 2002-2006

\begin{tabular}{lccccc}
\hline & \multicolumn{5}{c}{ No. of reported cases } \\
\cline { 2 - 6 } Province/territory & 2002 & 2003 & 2004 & 2005 & $2006 \dagger$ \\
\hline Newfoundland and Labrador & 0 & 0 & 0 & 0 & 0 \\
Prince Edward Island & 0 & 0 & 0 & $1^{*}$ & 0 \\
Nova Scotia & 0 & $2^{*}$ & 0 & $1^{*}$ & 0 \\
New Brunswick & 0 & $1^{*}$ & 0 & $1^{*}$ & 0 \\
Quebec & 20 & 17 & 3 & 6 & 0 \\
Ontario & 394 & 89 & 14 & 101 & 0 \\
Manitoba & 0 & 142 & 3 & 58 & 10 \\
Saskatchewan & 0 & 947 & 5 & 58 & 0 \\
Alberta & 2 & 275 & 1 & 10 & 0 \\
British Columbia & 0 & $20^{*}$ & 0 & 0 & 0 \\
Yukon Territory & 0 & $1^{*}$ & 0 & 0 & 0 \\
Northwest Territories & 0 & 0 & 0 & 0 & 0 \\
\hline Nunavut & 0 & 0 & 0 & 0 & 0 \\
\hline Total (no. of deaths) & $416(20)$ & $1494(14)$ & $26(2)$ & $236(12)$ & $10(0)$ \\
\hline Rerayyyyyy
\end{tabular}

*Related to travel outside the province/territory.

†As of 2006 Aug. 12. 
tres, or to public education campaigns urging people to cover up and use repellants when they venture outdoors.

"Certainly, if older people take those messages seriously, the more severe forms and manifestations of the fatal form of the disease are going to be seen less frequently," Rau says, adding that physicians are now far more familiar with the virus and more likely to diagnose and treat milder indications, so there are fewer instances of progression to meningitis and encephalitis and death.

But rising human immunity doesn't appear to be a factor, Rau insists. Studies indicate only about $3 \%$ of the population remains immune.

The reality is Canadians must now consider mosquitos as "more than a nuisance," Rau adds. "We never had to do this before 2002. So it's kind of an end of innocence for us." - Wayne Kondro, CMAJ

DOI:Io.1503/cmaj.06I045

\section{Alberta doctors seek relief}

\section{from oil patch boom}

I t's boom time in the oil patch, which has traditionally meant a run on gold faucets and bidding wars for houses. This time around, the economic explosion prompted by rising world oil prices has led to a population boom - 25900 more people in the first quarter of 2006 alone - and a resulting immediate shortage of 1000 physicians who, in turn, face escalating overhead costs.

The shortage of physicians has become so acute that regional health authorities have been forced to close hospital units, including a shutdown of the intensive care unit at Queen Elizabeth II Hospital in Grande Prairie in early August due to a shortage of internists, as well as a 24-hour closure of the surgery room in the Sturgeon Community Hospital in St. Albert, because of a shortage of anesthetists.

Compounding the boom time issues is the provincial government's seeming state of impasse as it races to replace Premier Ralph Klein as Conservative
Party leader. Funding has expired for programs to improve physician efficiency, like the creation of primary care networks, and for computerized medical records in doctors' offices.

In addition, physicians have been without a contract since Mar. 3I. Alberta Medical Association President Dr. Tzu-Kuang Lee says the failure to negotiate a new 2-year agreement will only make it more difficult to attract the requisite physicians to meet demand or, in turn, for them to recruit and retain staff in the red-hot labour market.

A tripartite committee, comprised of AMA, government and regional health authority representatives, has projected the province needs Iooo new doctors, and Lee surmises that will rise to 1500 within 5 years.

The AMA wants the province to adopt a provincial recruitment strategy, provide financial assistance to help cover high overhead costs and establish 